\title{
TRANSIENT ABSORPTION OF COPPER SELENIDE NANOWIRES OF DIFFERENT STOICHIOMETRY
}

\author{
G. Juška ${ }^{a}$, V. Gulbinas ${ }^{a}$, and A. Jagminas ${ }^{b}$ \\ ${ }^{a}$ Institute of Physics, Center for Physical Sciences and Technology, Savanoriu 231, LT-02300 Vilnius, Lithuania \\ E-mail: ged.juska@gmail.com \\ ${ }^{\mathrm{b}}$ Institute of Chemistry, Center for Physical Sciences and Technology, A. Goštauto 9, LT-01108 Vilnius, Lithuania
}

Received 19 August 2009; revised 18 April 2010; accepted 17 June 2010

\begin{abstract}
Copper selenide nanowires of different stoichiometric compositions and having different density of defects that form intraband states embedded in a porous alumina layer have been investigated by means of a femtosecond absorption pump-probe technique. Depending on the formation conditions, different samples have different absorption spectra in the near-infrared spectral range, but all of them show bleaching of the most intense absorption bands, which competes with the induced absorption of free charge carriers. A transient absorption relaxation takes place in two steps, with time constants of about 1 ps and several tens of ps. Relative contribution of the fast relaxation component increases in samples with the higher density of defect states forming the recombination centres.
\end{abstract}

Keywords: copper selenide nanowires, transient absorption

PACS: $71.20 . \mathrm{Nr}, 62.23 . \mathrm{Hj}$, 78.47.J-, 78.67.Bf

\section{Introduction}

Nonstoichiometric copper selenide $\mathrm{Cu}_{2-x} \mathrm{Se}(x=$ $0-0.25$ ) is a self-doping superionic $p$-type semiconductor with a density of free holes normally exceeding $10^{22} \mathrm{~cm}^{-3}$ [1-3]. A wide range of copper selenide stoichiometric $\left(\mathrm{Cu}_{2} \mathrm{Se}, \mathrm{Cu}_{3} \mathrm{Se}_{2}, \mathrm{CuSe}_{2}, \mathrm{CuSe}\right)$ and nonstoichiometric $\left(\mathrm{Cu}_{2-x} \mathrm{Se}\right)$ compositions and their crystallographic forms have been synthesized and characterized during several decades $[4,5]$. The band gap of copper selenide is not well defined because of the wide variety of stoichiometric forms, presence of high density of dislocations and defects, energy barrier height variations in grains of polycrystalline films, and quantum confinement effects [6]. $\mathrm{Cu}_{2-x} \mathrm{Se}$ is usually reported to possess a direct band gap of 2.21-2.39 eV and an indirect band gap of 1.2-1.7 eV [7-9]. Thin films of copper selenide are of particular interest for formation of heterojunction solar cells where they are used as absorbing [10] or window [11] layers. Copper selenide is a precursor material of $\mathrm{CuInSe}_{2}$, used for highly efficient photovoltaic elements [5, 12]. Attempts of application of copper selenide for optical filters [13], saturable absorbers for a passive mode locking of near-IR solid-state lasers [14], humidity sensors [15], highly effective hole injection layers for use with $p$-type organic semiconductors [3], novel nanotubes [16] have also been recently reported.
Application of copper selenide for more sophisticated devices requires full-scale characterization of the material. Ultrafast relaxational processes that are essential for nonlinear optical elements and novel electronic nanodevices are barely investigated in copper selenide. Our investigations presented in this paper were stimulated by a very wide dispersion of steady-state optical parameters of copper selenide that indicate presumably different energetic structures and relaxation mechanisms of nonequilibrium photogenerated carriers. Our previous study of nonstoichiometric $\mathrm{Cu}_{2-x} \mathrm{Se}$ nanowires [17] revealed bleaching of the near-infrared (IR) absorption band and ultrafast transient absorption dynamics. Here we present transient absorption investigations of copper selenide nanowires with different stoichiometric compositions and different defect densities obtained by varying the material synthesis and post-formation treatment. We demonstrate that linear and nonlinear optical properties of copper selenide nanowire arrays loaded inside alumina template pores by electrodeposition crucially depend on the nanowire composition. 


\section{Experiment}

The samples under investigation were densely packaged nanowire arrays of a dominant nonstoichiometric $\mathrm{Cu}_{2-x} \mathrm{Se}(x \sim 0.25)$ or stoichiometric $\mathrm{Cu}_{3} \mathrm{Se}_{2}$ fabricated inside alumina pores by an alternating current electrodeposition. In preparation of alumina templates, Al foil (99.99\% purity, $100 \mu \mathrm{m}$ thickness) specimens were annealed at $500{ }^{\circ} \mathrm{C}$ for 3 hours, etched in $1.5 \mathrm{M}$ $\mathrm{NaOH}$ at $60^{\circ} \mathrm{C}$ for $30 \mathrm{~s}$, electropolished in an ethanol $(\mathrm{EtOH})$ solution of perchloric acid and glycerol at $17 \mathrm{~V}$ $\mathrm{dc}$ for $3 \mathrm{~min}$, and thoroughly rinsed in an EtOH and distilled water. The oxide film formed during electropolishing was removed from the substrate by etching in a $0.24 \mathrm{M} \mathrm{Na}_{2} \mathrm{CO}_{3}$ solution at $80^{\circ} \mathrm{C}$ for $60 \mathrm{~s}$. Anodization was performed in thermostated and vigorously stirred electrolytes either of $1.2 \mathrm{M} \mathrm{H}_{2} \mathrm{SO}_{4}\left(10^{\circ} \mathrm{C}, 15 \mathrm{~V}\right)$ or $0.3 \mathrm{M} \mathrm{H}_{2} \mathrm{C}_{2} \mathrm{O}_{4}\left(17^{\circ} \mathrm{C}, 40 \mathrm{~V}\right)$ until the alumina matrix of about $10 \mu \mathrm{m}$ thickness was grown. The specimens were sonicated in $0.5 \mathrm{M} \mathrm{H}_{3} \mathrm{PO}_{4}$ at $30^{\circ} \mathrm{C}$ for $25 \mathrm{~min}$ to widen the pores. The as-anodized samples were washed with DI water and incubated in a bath for an electrochemical deposition of copper selenide nanowire arrays. A custom-made supply of an alternating current (ac, $50 \mathrm{~Hz}$ ) allowing us a simple control of the average current strength was used in the deposition set-up. Nonstoichiometric copper selenide $\mathrm{Cu}_{2-x}$ Se nanowires were grown using sulfuric acid alumina matrices (average $\varnothing_{\text {pore }} 15 \mathrm{~nm}$ ) in $0.03 \mathrm{CuSO}_{4}, 0.015 \mathrm{H}_{2} \mathrm{SeO}_{3}$, $0.05 \mathrm{MgSO}_{4}$ (in $\mathrm{M}$ ), and $\mathrm{H}_{2} \mathrm{SO}_{4}$ solution under 0.6 and $0.4 \mathrm{~A} \mathrm{dm}^{-2}$ (pH 1.9) and $0.2 \mathrm{~A} \mathrm{dm}^{-2}$ (pH 1.4) conditions. These specimens are referred to in this paper as Samples 1, 2, and 3, respectively. For a deposition of quite pure $\mathrm{Cu}_{3} \mathrm{Se}_{2}$ phase nanowires in the oxalic acid alumina template pores $\left(\varnothing_{\text {pore }} 48 \mathrm{~nm}\right.$ ) an aqueous solution composed of $0.033 \mathrm{CuSO}_{4}, 0.015 \mathrm{H}_{2} \mathrm{SeO}_{3}, 0.03$ $\mathrm{Al}_{2}\left(\mathrm{SO}_{4}\right)_{3}$ (in $\mathrm{M}$ ), and $\mathrm{H}_{2} \mathrm{SO}_{4}$ (to adjust the $\mathrm{pH}$ to 1.15 ), pre-electrolyzed by the alternating current, was used. This sample is referred to as Sample 4. Thermal treatment of the samples was conducted in an open programmable oven (Zhermack) within 150 to $350 \pm 2{ }^{\circ} \mathrm{C}$ temperature range for $60 \mathrm{~min}$.

X-ray diffraction (XRD) and optical investigations were carried out after detaching alumina templates encased with copper selenide nanowires from the substrate by till-side etching of aluminum in an acidic $0.1 \mathrm{M}$ $\mathrm{CuCl}_{2}$ solution. X-ray diffraction studies were performed with the diffractometer D8 (Bruker AXS, Germany) equipped with a Göbel mirror for $\mathrm{Cu} \mathrm{K}_{\alpha}$ radiation. A step-scan mode was used in a $2 \Theta$ range from 18 to $55^{\circ}$ with a step of $0.04^{\circ}$ and a counting time of $15 \mathrm{~s}$ per step.

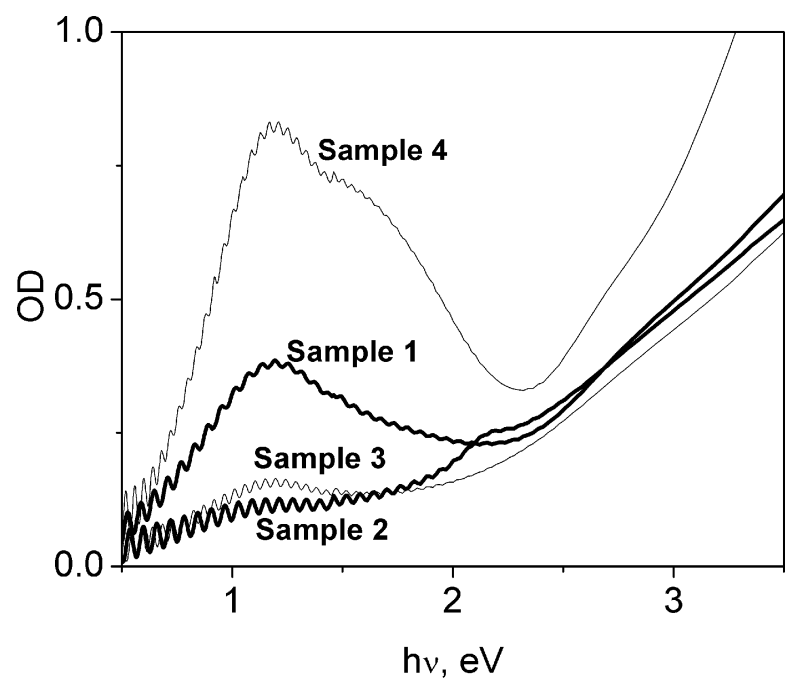

Fig. 1. Steady-state absorption spectra of $48 \mathrm{~nm} \mathrm{Cu}_{3} \mathrm{Se}_{2}$ (Sample 4) and $15 \mathrm{~nm}$ diameter $\mathrm{Cu}_{2-x}$ Se (Samples 1, 2, and 3) nanowires.

Copper selenide nanowires embeded in a porous alumina layer were investigated by means of ultrafast transient absorption technique. A conventional femtosecond two-beam pump-probe spectrometer based on a passively-mode locked amplified Ti:sapphire laser with the pulse duration of $120 \mathrm{fs}$ (FWHM) and the repetition rate of $1 \mathrm{kHz}$ was used. A fundamental laser radiation was used to pump the Light Conversion parametric amplifier TOPAS. The samples were excited with 1.65 or $2.88 \mathrm{eV}$ photon energy pulses and induced optical nonlinearities were probed with a white-light continuum generated in a sapphire crystal.

\section{Results and discussion}

Steady-state absorption spectra of the investigated nanowires are presented in Fig. 1. A broad absorption band present in the near-infrared spectral region right below the edge of the fundamental absorption band is a common feature of nanostructures containing double valence copper (e.g. CuSe, $\mathrm{CuFeS}_{2}$ ) $[13,18,19]$. Middle-gap states are formed in these compositions and thus the additional low energy absorption band shall be attributed to electron transitions from these states to the conduction band. It is obvious from the steady-state absorption spectra that variations of the electrodeposition parameters and post-deposition treatment result in distinct optical properties of each sample. It was demonstrated that the peak intensity of the absorption band related to the middle-gap states depends on the degree of the sample oxidation [20] and its energetic position can be tuned within the spectral range of $0.8-1.25 \mathrm{eV}$ $[14,21]$. The sample annealing causes the most no- 


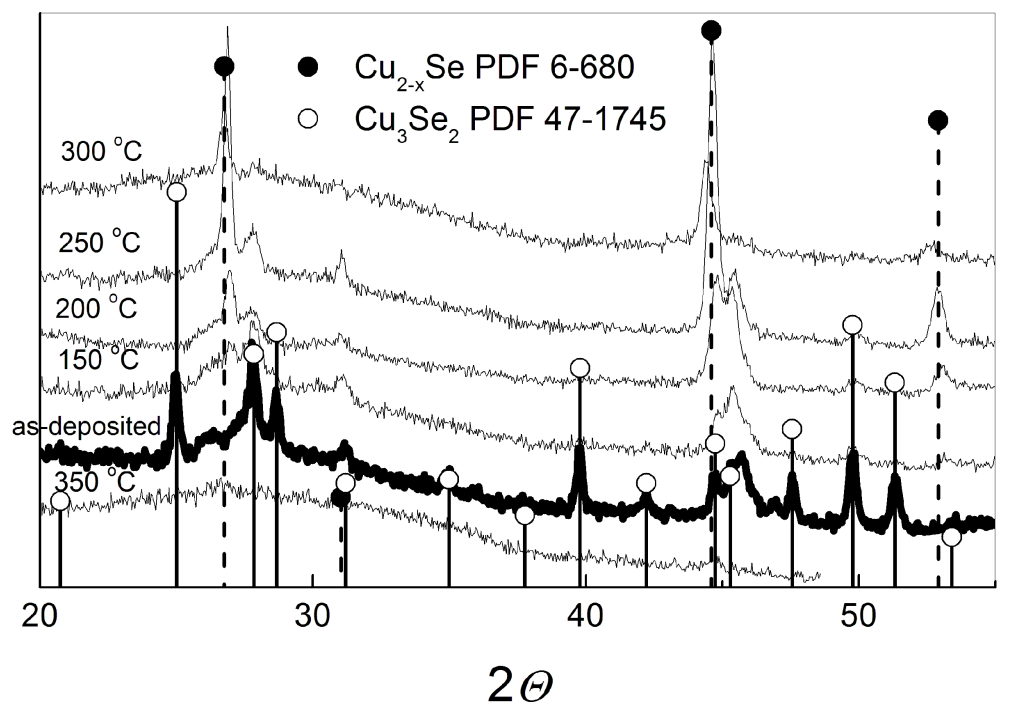

Fig. 2. XRD patterns of oxalic acid alumina template encased with copper selenide nanowires ( $\varnothing_{\text {pore }} 48 \mathrm{~nm}$ ) by ac deposition in the solution (M): $0.033 \mathrm{CuSO}_{4}, 0.015 \mathrm{H}_{2} \mathrm{SeO}_{3}, 0.03 \mathrm{Al}_{2}\left(\mathrm{SO}_{4}\right)_{3}$, and $\mathrm{H}_{2} \mathrm{SO}_{4}$ (down to $\mathrm{pH} 1.15$ ) at $0.5 \mathrm{~A} \mathrm{dm}^{-2}$ for 45 min before and after annealing in air at indicated temperatures for one hour.

table post-formation treatment effects. The XRD profiles presented in Fig. 2 demonstrate the transformation of the copper selenide stoichiometry induced by the sample annealing. A crystalline tetragonal $\mathrm{Cu}_{3} \mathrm{Se}_{2}$ phase identified by 12 well-defined peaks dominates right after the deposition. Annealing of the nanostructures causes transformation of the $\mathrm{Cu}_{3} \mathrm{Se}_{2}$ phase into the $\mathrm{Cu}_{2-x}$ Se phase. The $\mathrm{Cu}_{2-x} \mathrm{Se}$ phase dominates in samples annealed for 3 hours at $300^{\circ} \mathrm{C}$. A part of the absorption spectrum below the absorption edge of as-deposited $48 \mathrm{~nm}$ diameter nanowires (Sample 4) may be well approximated by the superposition of two Lorentzian shape bands with the peak maxima at 1.12 and $1.67 \mathrm{eV}$ and FWHM of 0.61 and $1.48 \mathrm{eV}$, respectively. As demonstrated in [22], the near-infrared absorption band with the maximum at $\sim 1.12 \mathrm{eV}$ belongs to the nonstoichiometric $\mathrm{Cu}_{2-x} \mathrm{Se}$ phase. Even a small fraction of this phase undetectable by XRD is sufficient to form the absorption band (Fig. 1). Several investigated samples $(1,2$, and 3$)$ filled with $\mathrm{Cu}_{2-x}$ Se possess slightly different steady-state optical features due to the alternation of their synthesis procedures. The second band at $1.67 \mathrm{eV}$ shall be attributed to the $\mathrm{Cu}_{3} \mathrm{Se}_{2}$ phase. It appears that a lower current density used during the electrochemical deposition of the material leads to the formation of smaller density of the middle-gap states that are responsible for the low energy absorption band, though the intrinsic absorption remains unaffected. Sinusoidal absorption modulations prominent in the infrared region are obviously due to the optical interference effects in a thin alumina layer.
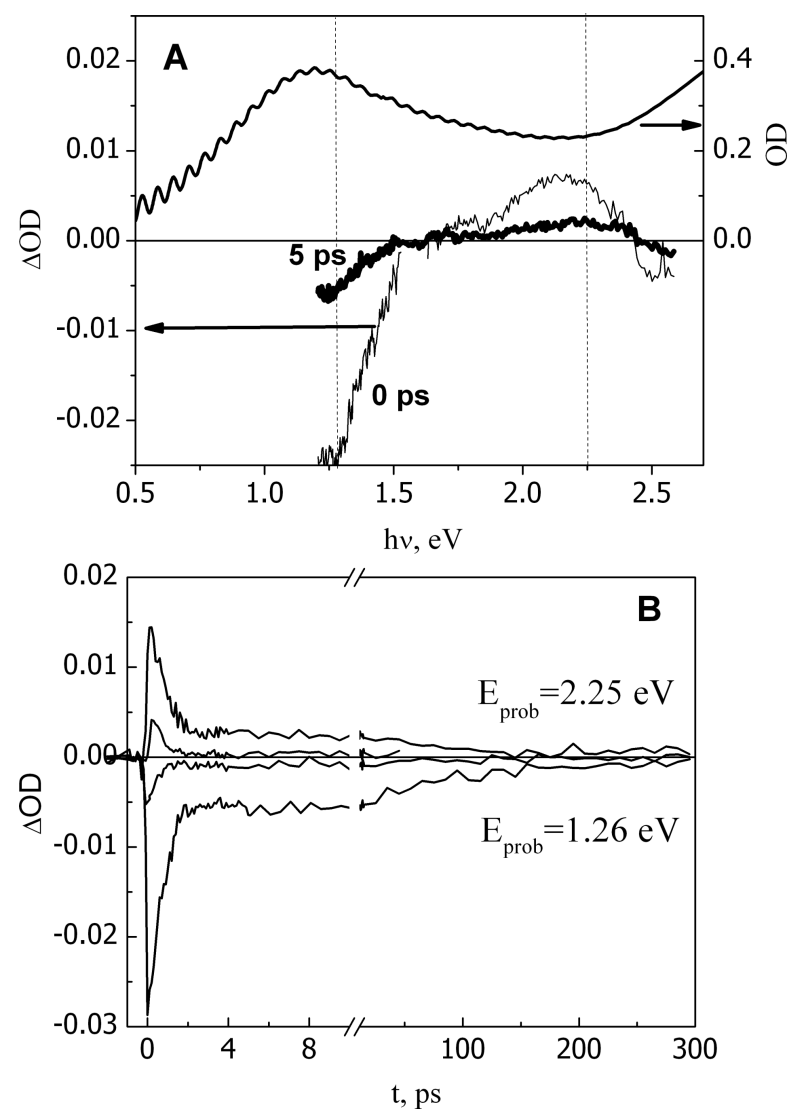

Fig. 3. (a) Transient absorption spectra and (b) kinetics of the Sample 1. Dashed lines in (a) indicate the spectral position of probed kinetics. Optical changes in the sample were induced by $2.26 \mathrm{eV}$ photon energy and $0.3 \mathrm{~mJ} / \mathrm{cm}^{2}$ (higher intensity curves) or $0.063 \mathrm{~mJ} / \mathrm{cm}^{2}$ energy density pulses.

Transient absorption spectra and kinetics of a copper selenide obtained in different samples under $2.88 \mathrm{eV}$ 

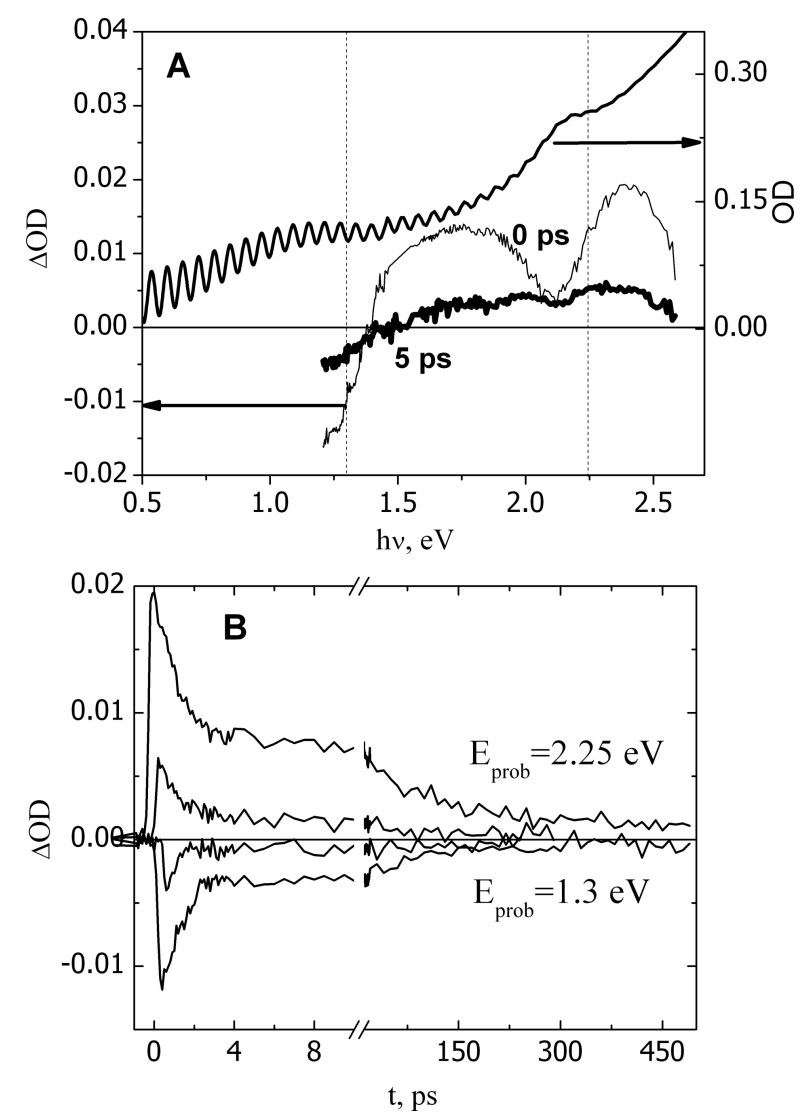

Fig. 4. (a) Transient absorption spectra and (b) kinetics of the Sample 2. Dashed lines in (a) indicate the spectral position of probed kinetics. Optical changes in the sample were induced by $2.26 \mathrm{eV}$ photon energy and $0.3 \mathrm{~mJ} / \mathrm{cm}^{2}$ (higher intensity curves) or $0.063 \mathrm{~mJ} / \mathrm{cm}^{2}$ energy density pulses.

excitation photon energy are presented in Figs. 3-5. Transient absorption spectra and kinetics in nanowires excited with lower energy photons $(1.65 \mathrm{eV})$ were very similar, therefore not presented. A similar weak dependence on the excitation photon energy of the transient absorption properties of a copper selenide was also reported in [17]. We have suggested that during the first $100 \mathrm{fs}$ the nonequilibrium carriers thermalize and relax through the high density manifold of local states to the same energy distribution independently of the initially created state.

Transient absorption spectra of Sample 1 with $15 \mathrm{~nm}$ diameter nanowires are presented in Fig. 3(a). This sample has a clearly expressed steady state absorption band in the near-infrared region. The transient absorption spectra indicate that at least two main concurrent nonlinear optical effects of a similar importance, namely absorption bleaching and excited state absorption, compete and cause negative or positive absorbance changes in different spectral regions. Bleaching of the additional absorption band at $1.2 \mathrm{eV}$ dominates in
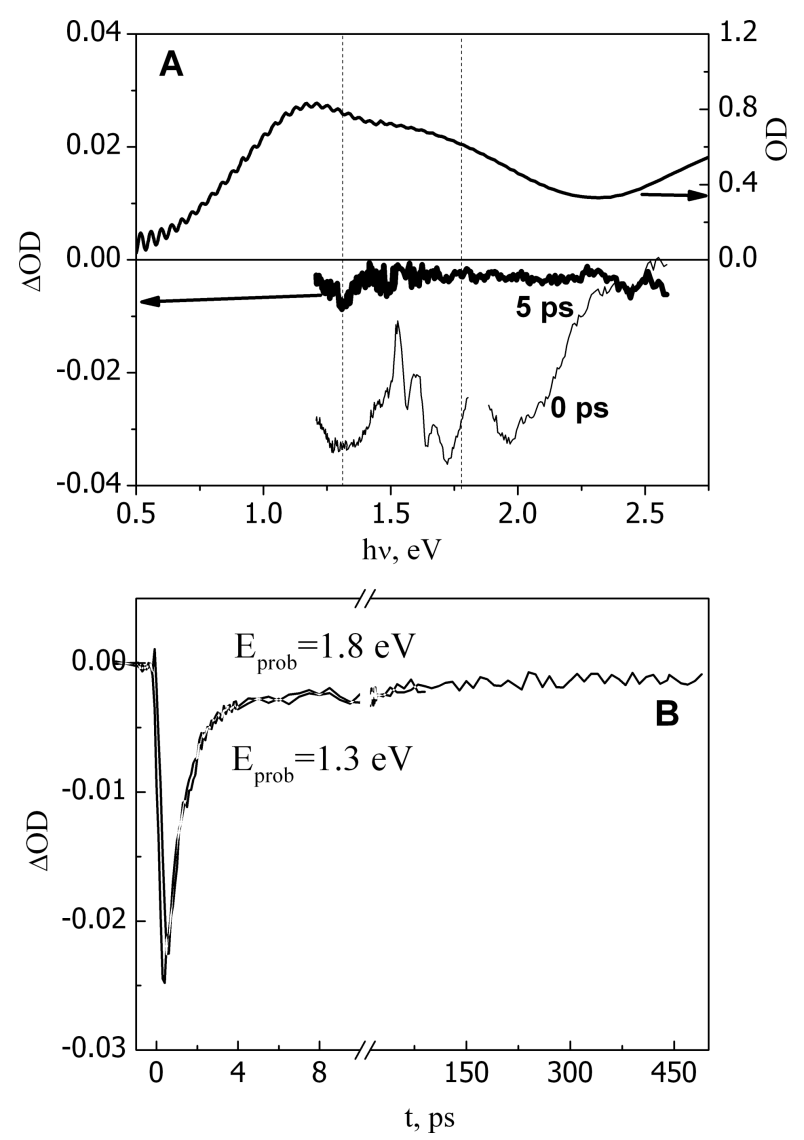

Fig. 5. (a) Transient absorption spectra and (b) kinetics of the Sample 4. Dashed lines in (a) indicate the spectral position of probed kinetics. Optical changes in the sample were induced by $2.26 \mathrm{eV}$ photon energy and $0.3 \mathrm{~mJ} / \mathrm{cm}^{2}$ energy density pulses.

the IR region. The bleaching is clearly caused by the conduction band state filling as presumable transitions from the middle-gap states to the conduction band are blocked. An induced absorption dominates in the visible spectral range. We assume that the absorption by free carriers gives rise to the induced absorption. The differential absorption spectrum measured at 5 ps delay time has basically the same shape. This indicates that either only two transient species are involved in the relaxation process or that material absorbance in some intermediate state is very similar to that in the initially excited state.

Figure 3(b) shows the transient absorption kinetics probed at 1.25 and $2.26 \mathrm{eV}$ in Sample 1 at two different excitation intensities. Transient absorption kinetics indicate complex relaxation process. The rise of the transient absorption changes is very fast, limited by the time resolution of the experimental set-up. The fast initial decay followed by the slower one indicates at least two relaxation mechanisms. Characteristic relaxation time constants were obtained by fitting kinetics with a biexponential decay function. Comparison of the decay pa- 
rameters confirms visual similarity of the decay kinetics probed at 2.25 and $1.26 \mathrm{eV}$. Similar shapes of the transient absorption spectrum at different delay times and similar kinetics in different spectral regions confirm that relaxation of the induced optical changes is mainly mediated by a nonequilibrium carrier recombination. In the case of the maximal excitation intensity, the initial and slower relaxation components are characterized by 0.71 and 120 ps time constants respectively. The induced optical changes relax to about $1 / 5$ of the initial value during the fast relaxation. At lower excitation intensity the initial relaxation is slightly faster, of about $0.55 \mathrm{ps}$, and the slow component is very weak or barely exists.

The transient absorption spectra and kinetics are in agreement with the energy scheme of copper selenide nanoparticles containing double valence copper as suggested in $[17,20,23,24]$. This scheme suggests the presence of two intermediate energy levels of different types: deep recombination levels and shallow trapping levels. The scheme reasonably explains the nature of the fast and slow relaxation components. The initial fast relaxation rate and its relative amplitude are mediated by the concentration of deep recombination centres. Saturation of this recombination channel at high excitation intensity leads to population of the long-lived trapping states, and the slow relaxation component appears.

Transient absorption data of Sample 2 with a weakly expressed IR absorption band are presented in Fig. 4. Despite obvious differences of the steady-state absorption spectra between Samples 1 and 2, transient absorption properties are quite similar. An induced absorption dominates in the visible spectral region and an absorption bleaching band appears in the near-infrared region. It indicates that a notably lower concentration of the middle-gap states is still sufficient to yield a strong bleaching effect. The isosbestic point is red shifted to $1.4 \mathrm{eV}$. The red shift is naturally explained by the competition of the absorption bleaching and induced absorption effects: weaker absorption bleaching outweighs the induced absorption in a narrower spectral region. The dip at $2.1 \mathrm{eV}$ in the induced absorption spectrum obtained at the initial time after excitation is an exceptional feature of this sample. Its position coincides with the weak additional band in the steady-state absorption spectrum, which is most likely caused by additional intraband defect level formed during the sample synthesis. Bleaching of this band partly compensates the induced absorption. Transient absorption kinetics is very similar to that observed in Sample 1 with the major difference in the ratio of contributions of the fast and slow relaxation components. The slow relaxation is notably more expressed and it contributes about 30$40 \%$ to the total relaxation. Evidently smaller fraction of created conduction carriers relax through lower density of recombination centres forming deep middle-gap states.

Differential absorption data of as-deposited $48 \mathrm{~nm}$ diameter nanowires of nearly pure $\mathrm{Cu}_{3} \mathrm{Se}_{2}$ (Sample 4) are presented in Fig. 5. Two bleaching bands with the maximum peak positions close to 1.3 and $1.7 \mathrm{eV}$ are clearly observed in the transient absorption spectrum at the initial time after excitation. The bleaching bands are slightly blue shifted compared to the stationary absorption bands. Sample 4 shows no induced absorption in the investigated spectral range; bleaching of the two strong absorption bands dominates over the free carrier absorption. The slow relaxation component is almost absent in these samples. Evidently nearly all created carriers relax during several picoseconds through the high density of interband recombination states.

Peculiarities of transient absorption relaxation processes in a mixed stoichiometric copper selenide phase sample can be explained by an internal disorder and high density of various defects forming intraband recombination centres. Additional absorption bands created by the mid-gap defect states are effectively bleached under the sample excitation independently of the excitation photon energy. These states also cause fast transient absorption relaxation as there is a clear correlation between the intensity of the additional absorption bands and the relative contribution of the fast relaxation component.

\section{Conclusions}

Investigation of nonlinear optical effects in copper selenide nanowires demonstrates a strong bleaching of the middle-gap states absorption band on the nearinfrared side, whereas an induced absorption dominates in the visible light spectral range in annealed nonstoichiometric copper selenide samples. Relaxation of induced absorbance changes is described by two processes-fast relaxation during initial several picoseconds followed by a slower component with the characteristic relaxation time constant of a few tens of picoseconds. The initial relaxation is more expressed in an as-deposited sample of nearly pure $\mathrm{Cu}_{3} \mathrm{Se}_{2}$ nanowires. $\mathrm{Cu}_{3} \mathrm{Se}_{2}$ phase leads to the formation of additional middle-gap states resulting in the rise of absorption 
bleaching in the visible spectral range. Higher concentration of the middle-gap states leads to more efficient ultrafast transient absorption relaxation of temporal optical features. The ability to adjust nonlinear optical properties of copper selenide nanowires is very attractive for their application. As-formed and nonannealed copper selenide nanostructures might be of a particular interest for fabrication of nonlinear optical elements that require fast optical response and nearly complete absorption bleaching recovery. Annealed samples with lower density of defects and local states can be used for devices that require longer lifetimes of nonequilibrium carriers.

\section{Acknowledgements}

The work was partly supported by the Lithuanian Science and Studies foundation. We also acknowledge Hab. Dr. R. Juškenas for the help with XRD spectra.

\section{References}

[1] A.N. Skomorokhov, D.M. Trots, M. Knapp, N.N. Bickulova, and $\mathrm{H}$. Fuess, Structural behaviour of $\beta$ $\mathrm{Cu}_{2-\delta} \mathrm{Se}(\delta=0,0.15,0.25)$ in dependence on temperature studied by synchrotron powder diffraction, J. Alloys Compounds 421, 64-71 (2006).

[2] B.A. Mansour, S.E. Demian, and H.A. Zayed, Determination of the effective mass for highly degenerate copper selenide from reflectivity measurements, J. Mater. Sci. Mater. Electron. 3, 249-252 (1992).

[3] H. Hiramatsu, I. Koizumi, Ki-Beom Kim, H. Yanagi, T. Kamiya, M. Hirano, N. Matsunami, and H. Hosono, Characterization of copper selenide thin film holeinjection layers deposited at room temperature for use with $p$-type organic semiconductors, J. Appl. Phys. 104, 113723 (2008).

[4] R.D. Heyding, The copper/selenium system, Can. J. Chem. 44, 1233-1236 (1966).

[5] Kyung Soo Kim, Han-Cheol Jeong, Jung Young Cho, Dong Hee Kang, Hong Ki Kim, Hee Min Yoo, and Il-Wun Shim, Preparation of $\operatorname{copper}(\mathrm{Cu})$ thin films by MOCVD and their conversion to copper selenide (CuSe) thin films through selenium vapor deposition, Bull. Korean Chem. Soc. 24(5), 647-649, (2003).

[6] S.R. Gosavi, N.G. Deshpande, Y.G. Gudage, and R. Sharma, Physical, optical and electrical properties of copper selenide (CuSe) thin films deposited by solution growth technique at room temperature, J. Alloys Compounds 448, 344-348 (2008).

[7] H. Li, Y. Zhu, S. Avivi, O. Palchik, J. Xiong, Y. Koltypin, V. Palchik, and A. Gedanken, Sonochemical process for the preparation of $\alpha$-CuSe nanocrystals, J. Mater. Chem. 12, 3723-3727 (2002).
[8] Al-Mamun and A.B.M.O. Islam, Characterization of copper selenide thin films deposited by chemical bath deposition technique, Appl. Surf. Sci. 238, 184-188 (2004).

[9] Y. Xie, X. Zheng, X. Jiang, J. Lu, and L. Zhu, Sonochemical synthesis and mechanistic study of copper selenides $\mathrm{Cu}_{2-x} \mathrm{Se}, \beta-\mathrm{CuSe}$, and $\mathrm{Cu}_{3} \mathrm{Se}_{2}$, Inorg. Chem. 41, 387-392 (2002).

[10] Wen S. Chen, J.M. Stewart, and R.A. Mickelsen, Polycrystalline thin-film $\mathrm{Cu}_{2-x} \mathrm{Se} / \mathrm{CdS}$ solar cell, Appl. Phys. Lett. 46, 1095 (1985).

[11] H. Okimura, T. Matsumae, and R. Makabe, Electrical properties of $\mathrm{Cu}_{2-x} \mathrm{Se}$ thin films and their application for solar cells, Thin Solid Films 71, 53-59 (1980).

[12] R.R. Pai, T.T. John, M. Lakshmi, K.P. Vijayakumar, and C.S. Kartha, Observation of phase transitions in chemical bath deposited copper selenide thin films through conductivity studies, Thin Solid Films 473, 208-212 (2005).

[13] V.S. Gurin, A.A. Alexeenko, S.A. Zolotovskaya, and K.V. Yumashev, Copper and copper selenide nanoparticles in the sol-gel matrices: Structural and optical, Mater. Sci. Eng. C 26, 952-955 (2006).

[14] R. Subas, G. Statkutè, I. Mikulskas, R. Ragalevičius, A. Jagminas, and R. Tomašiūnas, Optical investigation and application of copper selenide nanowires, Lithuanian J. Phys. 47(3), 361-364 (2007).

[15] Jun Xu, Weixin Zhang, Zeheng Yang, Shaixia Ding, Chunyan Zeng, Lingling Chen, Qiang Wang, and Shihe Yang, Large-scale synthesis of long crystalline $\mathrm{Cu}_{2-x} \mathrm{Se}$ nanowire bundles by water-evaporationinduced self-assembly and their application in gas sensing, Adv. Funct. Mater. 19, 1759-1766 (2009).

[16] Yang Jiang, Yue Wu, Bo Xie, Shuyuan Zhang, and Yitai Qian, Room temperature preparation of novel $\mathrm{Cu}_{2-x}$ Se nanotubes in organic solvent, Nanotechnology 15, 283-286 (2004).

[17] G. Juška, A. Jagminas, and V. Gulbinas, Excitation relaxation in copper selenide nanowires, Phys. Status Solidi B 1082, 246 (2009).

[18] A. Jagminas, R. Juškènas, I. Gailiūtè, G. Statkutè, and R. Tomašiūnas, Electrochemical synthesis and optical characterization of copper selenide nanowire arrays within the alumina pores, J. Cryst. Growth 294, 343 (2006).

[19] K.V. Yumashev, V.S. Gurin, P.V. Prokoshin, V.B. Prokopenko, and A.A. Alexeenko, Nonlinear optical properties and laser applications of copper chalcogenide quantum dots in glass, Phys. Status Solidi B 3, 815 (2001).

[20] A.M. Malyarevich, K.V. Yumashev, N.N. Posnov, V.P. Mikhailov, and V.S. Gurin, Optical transient bleaching and induced absorption of surface-oxidized CuFeS nanoparticles, Appl. Phys. B 70, 111 (2000).

[21] A.M. Malyarevich, K.V. Yumashev, and A.A. Lipovskii, Semiconductor-doped glass saturable absorbers 
for near-infrared solid-state lasers, J. Appl. Phys. 103, 081301 (2008).

[22] A. Jagminas, R. Tomašiūnas, A. Krotkus, R. Juškėnas, and G. Aleksejenko, Fabrication and phase variation in annealed $\mathrm{Cu}_{3} \mathrm{Se}_{2}$ nanowire arrays, Appl. Surf. Sci. 255, 7739-7742 (2009).

[23] M.C. Brelle, C.L. Torres-Martinez, J.C. McNulty, R.K. Mehra, and J.Z. Zhang, Synthesis and character- ization of $\mathrm{Cu}_{x} \mathrm{~S}$ nanoparticles. Nature of the infrared band and charge-carrier dynamics, Pure Appl. Chem. 72, 101 (2000).

[24] A.M. Malyarevich, K.V. Yumashev, and A.A. Lipovskii, Semiconductor-doped glass saturable absorbers for near-infrared solid-state lasers, J. Appl. Phys. 103, 081301 (2008).

\title{
SKIRTINGOS STECHIOMETRIJOS VARIO SELENIDO NANOVIELŲ NENUOSTOVIOJI SUGERTIS
}

\author{
G. Juška ${ }^{\text {a }}$, V. Gulbinas ${ }^{\text {a }}$, A. Jagminas ${ }^{\text {b }}$ \\ ${ }^{a}$ Fiziniu ir technologijos mokslu centro Fizikos institutas, Vilnius, Lietuva \\ ${ }^{\mathrm{b}}$ Fiziniu ir technologijos mokslu centro Chemijos institutas, Vilnius, Lietuva
}

\section{Santrauka}

Vario selenidas - puslaidininkinė medžiaga, kurios įvairioms stechiometrinèms formoms būdingos savitos optinès savybès. Išskirtinė vario selenido nanostruktūru savybè, lyginant su tūriniu kristalu, - papildoma homogeniškai išplitusi sugerties juosta, turinti maksimumą ties $1,2 \mathrm{eV}$. Tyrimo objektas - poretame aliuminio oksido sluoksnyje elektrochemiškai nusodinto vario selenido nanovielų, dèl skirtingų sintezès ir apdorojimo parametru (srovès tankio, rūgštingumo, atkaitinimo temperatūros) besiskiriančiu optinèmis savybemis, stechiometrija (nuo beveik grynos $\mathrm{Cu}_{3} \mathrm{Se}_{2}$ iki nestechiometrinès $\mathrm{Cu}_{2-x} \mathrm{Se}$ fazės). Šių nanostruktūrų nenuostoviosios sugerties savybės $1,2-2,88 \mathrm{eV}$ intervale tirtos femtosekundi- nès laikinès skyros sugerties žadinimo zondavimo metodika. Tyrimas rodo, kad visais atvejais nestechiometriniam $\mathrm{Cu}_{2-x}$ Se priskiriamai sugerties juostai artimojoje infraraudonoje srityje būdingas stiprus sugerties praskaidrejimas, kuris atsistato po dviejų relaksacinių vyksmų - spartaus, pikosekundžių trukmès, ir lètesnio, trunkančio kelis šimtus pikosekundžių. Regimosios šviesos srityje dominuoja indukuota sugertis, kurios relaksacijos trukmė analogiška. Bandiniuose su $\mathrm{Cu}_{3} \mathrm{Se}_{2}$ faze beveik visi indukuoti sugerties pokyčiai atsistato per pirmąsias pikosekundes. Tokia kontroliuojamų optinių savybių įvairovè gali būti pritaikyta gaminant netiesinès optikos elementus. 